\title{
PD-L1 Expression and Tumor-infiltrating Lymphocytes in Breast Cancer: Clinicopathological Analysis in Women Younger than 40 Years Old
}

\author{
ZOI EVANGELOU ${ }^{1}$, ALEXANDRA PAPOUDOU-BAI ${ }^{1}$, GEORGIA KARPATHIOU ${ }^{2}$, \\ HELEN KOUREA ${ }^{3}$, SEVASTI KAMINA ${ }^{1}$, ANNA GOUSSIA ${ }^{1}$, HARALAMBOS HARISSIS ${ }^{4}$, \\ DIMITRIOS PESCHOS ${ }^{5}$ and ANNA BATISTATOU ${ }^{1}$ \\ ${ }^{1}$ Department of Pathology, University Hospital of Ioannina, Ioannina, Greece; \\ ${ }^{2}$ Department of Pathology, University Hospital of Saint-Etienne, Saint-Etienne, France; \\ ${ }^{3}$ Department of Pathology, University Hospital of Patras, Patras, Greece; \\ ${ }^{4}$ Department of Surgery, Breast Unit, University Hospital of Ioannina, Ioannina, Greece; \\ ${ }^{5}$ Department of Physiology, Faculty of Medicine, University of Ioannina, Ioannina, Greece
}

\begin{abstract}
Background/Aim: To evaluate the association between programmed cell death ligand 1 (PD-L1) expression on both tumor cells (TC) and inflammatory cells (IC), tumor infiltrating lymphocytes (TILs), $\mathrm{CD}^{+}$and $\mathrm{CDS}^{+}$ lymphocytes and other clinicopathological parameters in primary infiltrative breast cancer (IBC) of young women, a population shown to have a worse prognosis. Materials and Methods: A retrospective study was performed collecting data from patients younger than 40 years old. Forty-five young women with IBC were included. Whole tissue sections were used to evaluate all parameters. Results: Twenty percent (20\%) of cases showed PD-L1 expression by tumor cells (PDL1TC) and 44.4\% showed PD-L1 expression by immune cells (PDL1IC). Furthermore, $28.88 \%$ revealed high stromal TILs. PDLITC and PDL1IC expression were significantly associated with tumor diameter and expression of estrogen (ER) and progesterone (PR) receptors and Ki67. PDLITC expression was also associated with grade. High TILs were associated with tumor diameter, ER and Ki67 expression. PDL1TC, PDL1IC expression and TILs were associated with the density of $\mathrm{CD}^{+}$and $\mathrm{CD}^{+}$lymphocytes. Conclusion: Our results are similar to those of other age groups, as reported in the literature.
\end{abstract}

This article is freely accessible online.

Correspondence to: Zoi Evangelou, MD, Department of Pathology, University Hospital of Ioannina, Stavros Niarchos Avenue, Ioannina 45500, Greece. Tel. +30 6933026066, e-mail: zoe_evag@yahoo.com

Key Words: Breast cancer, young women, PD-L1, TILs.
Breast cancer is the most common malignancy diagnosed among women of all ages and the second malignancy to cause death, after lung cancer (1). Younger women with breast cancer have a higher risk of recurrence and death, compared to older women (2-6). Additionally, this patient group shares considerations that must be taken into account when treated, like fertility preservation, pregnancy, sexual life and external appearance (7-11).

Over the past decade great improvement in diagnosis, prognosis and treatment has been achieved, complementing the already established targeted-therapy against estrogen (ER) and progesterone receptors (PR), as well as human epidermal growth factor receptor 2 (HER2). The molecular subtyping of breast cancer, compared to the morphological features, have opened new horizons to the understanding of the complex pathogenetic pathways leading to this common neoplasm (12). From the available studies it appears that for primary infiltrative breast cancer (IBC) there are not considerable differences regarding the biological profile in various ages, excluding the genetically predisposed cases (13).

The development and progression of IBC is due to a complex system of multiple factors including those of the microenvironment such as stromal and immune cells (14). The latter knowledge in combination with perceiving the cancer - immunity cycle, has led numerous studies to focus on the tumor microenvironment of the host in several solid cancers, including IBC $(15,16)$. Over the decades, it has been proven that the presence of high tumor infiltrating lymphocytes (TILs) in solid tumors, such as lung, ovarian cancer, colorectal cancer, renal cell carcinoma, prostate cancer and head and neck cancers, as well as in breast cancer, is associated with better prognosis (17-25). 
Most recently, researchers have been focusing on programmed cell death 1 and programmed cell death ligand 1 (PD1/PD-L1) axis, one of the most common mechanisms of tumor cell escape in cancer (26). The programmed cell PD-1 is a $55-\mathrm{kDa}$ transmembrane protein located on the membrane surface of $\mathrm{CD}^{+} \mathrm{T}$ cells, NK T cells, B lymphocytes and dendritic cells. The most studied ligand of PD-1 is programmed cell death ligand 1 (PD-L1) or B7H1 or CD274 as otherwise known (27). PD-L1 is located on the membrane of various cell types such as hematopoietic cells e.g. B and T lymphocytes, dendritic cells, macrophages and mast cells, but also on nonhematopoietic cells such as endothelial, epithelial and muscle cells (28). Its levels in normal tissues are extremely low, whereas it is found overexpressed on neoplastic cells (29). PD1 is commonly expressed on T regulatory cells found in TILs of several solid cancers. Its interaction with PD-L1 located on the surface of neoplastic cells leads to decreased cytokine expression, suppression of further activation of $\mathrm{T}$ lymphocytes gets and elimination of immune response $(30,31)$.

The aim of the present study was to examine the expression of PD-L1 on both tumor cells (TC) and immune cells (IC), quantify TILs, $\mathrm{CD}^{+}$and $\mathrm{CD}^{+}$in $\mathrm{IBC}$ and investigate the association between these parameters, well as with other clinicopathologic parameters in the population of young women $\leq 40$-years-old.

\section{Materials and Methods}

Study group. We retrospectively searched the electronic data-base of the Pathology Department of the University Hospital of Ioannina, Ioannina, Greece. All patients were young women ( $\leq 40$ years old) with IBC treated surgically at the same Institution between 2011 and 2016. Forty-five cases of breast cancer were found, all of which were of the nonspecific type (NST); several parameters were studied including tumor size, histological grade, estrogen receptor (ER), progesterone receptor (PR), HER2 and Ki67 expression. Due to the limited number of cases of triple-negative cancer (TNC), further analysis of the IBC into molecular subtypes was not performed. Similarly, grade 1 IBC were excluded from the statistical analysis due to their limited number.

Quantification of TILs. Histopathological analysis of the lymphocytic infiltrate was performed according to the guidelines for clinical and research practice (32). Briefly, using the hematoxylin/eosin stained tissue sections, the percentage of stromal mononuclear cells, lymphocytes and plasma cells (polymorphonuclear leukocytes were excluded) were quantified within the tumor border. The evaluation did not include hot spots, TILs outside the tumor border, TILs in tumor zones with crush artifacts, necrosis, regressive hyalinization or areas of previous biopsy site. The quantification was as detailed as possible, dividing TILs in three groups $(\leq 10 \%, 11-60 \%$, and $>60 \%$ ). Ultimately, they were divided into two groups, low TILs $(<60 \%)$ and high TILs $(>60 \%)$. Further analysis was performed, identifying the composition of the TILs, using CD3 and CD8 antibodies. Each antibody was counted in five randomly selected high power fields at $400 \mathrm{x}$ magnification, and the counts were averaged (33). Positive CD3 or CD8 TILs up to 25 cells were considered as low ( $+1-25$ cells), whereas medium density was the
Table I. Clinicopathological characteristics of young women with breast cancer.

\begin{tabular}{|c|c|c|}
\hline Patient characteristics & $\mathrm{n}(=45)$ & $\%$ \\
\hline \multicolumn{3}{|l|}{ Tumor diameter } \\
\hline$\leq 2 \mathrm{~cm}$ & 22 & 48.89 \\
\hline$>2-5 \mathrm{~cm}$ & 19 & 42.22 \\
\hline$>5 \mathrm{~cm}$ & 4 & 8.89 \\
\hline \multicolumn{3}{|l|}{ Tumor grade } \\
\hline 1 & 2 & 4.45 \\
\hline 2 & 15 & 33.33 \\
\hline 3 & 28 & 62.22 \\
\hline \multicolumn{3}{|l|}{ In situ coexistence } \\
\hline Yes & 38 & 84.44 \\
\hline No & 7 & 15.56 \\
\hline \multicolumn{3}{|l|}{ No of tumors } \\
\hline Single & 39 & 86.67 \\
\hline Multiple & 6 & 13.33 \\
\hline \multicolumn{3}{|c|}{ Lymphovascular invasion } \\
\hline Yes & 24 & 53.33 \\
\hline No & 21 & 46.67 \\
\hline \multicolumn{3}{|l|}{ Perineural invasion } \\
\hline Yes & 6 & 13.33 \\
\hline No & 39 & 86.67 \\
\hline \multicolumn{3}{|l|}{ Lymph node metastasis } \\
\hline Yes & 21 & 46.67 \\
\hline No & 24 & 53.33 \\
\hline \multicolumn{3}{|c|}{ Estrogen receptors expression } \\
\hline Positive & 32 & 71.11 \\
\hline Negative & 13 & 28.89 \\
\hline \multicolumn{3}{|c|}{ Progesterone receptors expression } \\
\hline Positive & 38 & 84.44 \\
\hline Negative & 7 & 15.56 \\
\hline \multicolumn{3}{|l|}{ MIB1/ki67 expression } \\
\hline Low $(<20)$ & 20 & 44.44 \\
\hline High $(\geq 20)$ & 25 & 55.56 \\
\hline \multicolumn{3}{|l|}{ HER2 expression } \\
\hline Positive & 12 & 26.67 \\
\hline Negative & 33 & 73.33 \\
\hline \multicolumn{3}{|l|}{ TILs } \\
\hline Low & 32 & 71.11 \\
\hline High & 13 & 28.89 \\
\hline \multicolumn{3}{|l|}{ Stromal CD3 count } \\
\hline Low (1) & 25 & 55.56 \\
\hline High (2-3) & 20 & 44.44 \\
\hline \multicolumn{3}{|l|}{ Stromal CD8 count } \\
\hline Low (1) & 25 & 55.56 \\
\hline High (2-3) & 20 & 44.44 \\
\hline \multicolumn{3}{|l|}{ PDL1TC expression } \\
\hline Positive & 9 & 20 \\
\hline Negative & 36 & 80 \\
\hline \multicolumn{3}{|l|}{ PDL1IC expression } \\
\hline Positive & 20 & 44.44 \\
\hline Negative & 25 & 55.56 \\
\hline
\end{tabular}

count of 26 up to 50 cells (++26-50 cells) and high the count of 51 cells or more $(+++\geq 51$ cells). As with TILs quantification, CD3 and CD8 were divided in two groups, low (1-25 cells) and high (>26 cells) for statistical purposes. 
Table II. TILs and PDL1 correlation with clinicopathological parameters.

\begin{tabular}{|c|c|c|c|c|c|c|c|c|c|}
\hline & \multicolumn{3}{|c|}{ TILs } & \multicolumn{3}{|c|}{ PDL1TC } & \multicolumn{3}{|c|}{ PDL1IC } \\
\hline & $\begin{array}{l}\text { High } \mathrm{n} \\
(\%)\end{array}$ & $\begin{array}{l}\text { Low n } \\
(\%)\end{array}$ & $p$-Value & $\begin{array}{c}\text { Positive } \mathrm{n} \\
(\%)\end{array}$ & $\begin{array}{l}\text { Negative } \mathrm{n} \\
(\%)\end{array}$ & $p$-Value & $\begin{array}{l}\text { Positive } \mathrm{n} \\
(\%)\end{array}$ & $\begin{array}{c}\text { Negative } \mathrm{n} \\
(\%)\end{array}$ & $p$-Value \\
\hline \multicolumn{10}{|c|}{ Tumor diameter } \\
\hline$\leq 2 \mathrm{~cm}$ & $3(13.64 \%)$ & $19(86.36 \%)$ & 0.016 & $1(4.55 \%)$ & $21(95.45 \%)$ & 0.023 & $7(31.82 \%)$ & $15(68.18 \%)$ & 0.185 \\
\hline$>2-5 \mathrm{~cm}$ & $10(52.63 \%)$ & $9(47.36 \%)$ & & $7(36.84 \%)$ & $12(63.16 \%)$ & & $10(52.63)$ & $9(47.37)$ & \\
\hline$>5 \mathrm{~cm}$ & 0 & $4(100 \%)$ & & $1(25 \%)$ & $3(75 \%)$ & & $3(75 \%)$ & $1(25 \%)$ & \\
\hline \multicolumn{10}{|c|}{ Tumor grade $(n=43)^{*}$} \\
\hline 2 & $2(13.33 \%)$ & $13(86.67 \%)$ & 0.096 & 0 & $15(100 \%)$ & 0.017 & $4(22.22 \%)$ & $14(77.78 \%)$ & 0.199 \\
\hline 3 & $11(39.28 \%)$ & $17(60.71 \%)$ & & $9(32.14 \%)$ & $19(67.86 \%)$ & & $14(50 \%)$ & $14(50 \%)$ & \\
\hline \multicolumn{10}{|c|}{ In situ coexistence } \\
\hline Yes & $10(26.31 \%)$ & $28(73.68 \%)$ & 0.394 & $7(18.42 \%)$ & $31(81.57 \%)$ & 0.614 & $16(42.11 \%)$ & $22(57.89 \%)$ & 0.682 \\
\hline No & $3(42.86 \%)$ & $4(57.14)$ & & $2(28.57 \%)$ & $5(71.42 \%)$ & & $4(57.14 \%)$ & $3(42.86 \%)$ & \\
\hline \multicolumn{10}{|l|}{ No of tumors } \\
\hline Single & $1(2.22 \%)$ & $27(96.42 \%)$ & 0.656 & $8(20.51 \%)$ & $31(79.48 \%)$ & 1.000 & $17(43.59 \%)$ & $22(56.41 \%)$ & 1.000 \\
\hline Multiple & $12(70.58 \%)$ & $5(29.41 \%)$ & & $1(16.66 \%)$ & $5(83.33 \%)$ & & $3(50 \%)$ & $3(50 \%)$ & \\
\hline \multicolumn{10}{|c|}{ Lymphovascular invasion } \\
\hline Yes & $8(33.33 \%)$ & $16(66.66 \%)$ & 0.528 & $7(29.16 \%)$ & $17(70.83 \%)$ & 0.143 & $12(50 \%)$ & $12(50 \%)$ & 0.423 \\
\hline No & $5(23.80 \%)$ & $16(76.19 \%)$ & & $2(9.51 \%)$ & $19(90.47 \%)$ & & $8(38.10 \%)$ & $13(61.90 \%)$ & \\
\hline \multicolumn{10}{|c|}{ Perineural invasion } \\
\hline Yes & 0 & $6(100 \%)$ & 0.160 & $2(33.33 \%)$ & $4(66.66 \%)$ & 0.583 & $3(50 \%)$ & $3(50 \%)$ & 1.000 \\
\hline No & $13(33.33 \%)$ & $26(66.66 \%)$ & & $7(17.94 \%)$ & $32(82.05 \%)$ & & $17(43.59 \%)$ & $22(56.41 \%)$ & \\
\hline \multicolumn{10}{|c|}{ Lymph node metastasis } \\
\hline Yes & $5(23.80 \%)$ & $16(76.19 \%)$ & 0.528 & $4(19.04 \%)$ & $17(80.95 \%)$ & 1.000 & $10(47.62 \%)$ & $11(52.38 \%)$ & 0.688 \\
\hline No & $8(33.33 \%)$ & $16(66.66 \%)$ & & $5(20.83 \%)$ & $19(79.16 \%)$ & & $10(41.67 \%)$ & $14(58.33 \%)$ & \\
\hline \multicolumn{10}{|c|}{ ER expression } \\
\hline Positive & $4(12.5 \%)$ & $28(87.5 \%)$ & 0.000 & $2(6.25 \%)$ & $30(93.75 \%)$ & 0.001 & $9(28.13 \%)$ & $23(71.87 \%)$ & 0.001 \\
\hline Negative & $9(69.23 \%)$ & $4(30.76 \%)$ & & $7(53.84 \%)$ & $6(46.15 \%)$ & & $11(84.62 \%)$ & $2(15.38 \%)$ & \\
\hline \multicolumn{10}{|l|}{ PR expression } \\
\hline Positive & $9(23.28 \%)$ & $29(76.32 \%)$ & 0.168 & $4(10.52 \%)$ & $34(89.47 \%)$ & 0.002 & $13(34.21 \%)$ & $25(65.79 \%)$ & 0.001 \\
\hline Negative & $4(57.14 \%)$ & $3(42.86 \%)$ & & $5(71.42 \%)$ & $2(28.57 \%)$ & & $7(100 \%)$ & 0 & \\
\hline \multicolumn{10}{|c|}{ MIB1/ki67 expression } \\
\hline Low $(<20)$ & $2(10 \%)$ & $18(90 \%)$ & 0.012 & $1(5 \%)$ & $19(95 \%)$ & 0.030 & $6(30 \%)$ & $14(70 \%)$ & 0.081 \\
\hline $\operatorname{High}(\geq 20)$ & $11(44 \%)$ & $14(56 \%)$ & & $8(32 \%)$ & $17(68 \%)$ & & $14(56 \%)$ & $11(44 \%)$ & \\
\hline \multicolumn{10}{|c|}{ HER2 expression } \\
\hline Positive & $6(50 \%)$ & $6(50 \%)$ & 0.076 & $2(16.66 \%)$ & $10(8.33 \%)$ & 1.000 & $7(58.33 \%)$ & $5(41.67 \%)$ & 0.258 \\
\hline Negative & $7(21.21 \%)$ & $26(78.78 \%)$ & & $7(21.21 \%)$ & $26(78.78 \%)$ & & $13(39.39 \%)$ & $20(60.61 \%)$ & \\
\hline \multicolumn{10}{|c|}{ Stromal CD3 count } \\
\hline Low & 0 & $25(100 \%)$ & 0.000 & $2(8 \%)$ & $23(92 \%)$ & 0.024 & $7(28 \%)$ & $18(72 \%)$ & 0.013 \\
\hline High & $13(65 \%)$ & $7(35 \%)$ & & $7(35 \%)$ & $13(65 \%)$ & & $13(65 \%)$ & $7(35 \%)$ & \\
\hline \multicolumn{10}{|c|}{ Stromal CD8 count } \\
\hline Low & 0 & $25(100 \%)$ & 0.000 & $2(8 \%)$ & $23(92 \%)$ & 0.024 & $7(28 \%)$ & $18(72 \%)$ & 0.013 \\
\hline High & $13(65 \%)$ & $7(35 \%)$ & & $7(35 \%)$ & $13(65 \%)$ & & $13(65 \%)$ & $7(35 \%)$ & \\
\hline
\end{tabular}

*Grade 1 tumors were excluded from the statistical analysis due to their limited number.

PD-L1 immunohistochemistry. PD-L1 immunohistochemistry assessment was performed on whole-tissue sections using the rabbit monoclonal antibody, clone E1L3N (Cell Signaling Technologies, Danvers, MA, USA). Both tumor cells (TC) and immune cells (IC) were evaluated. Human placenta tissue was used as positive control in parallel with the sections. TC staining was defined as partial or complete membranous staining, while IC staining was defined as cytoplasmic or membranous staining in lymphocytes or macrophages, using the number of IC within the stroma of the tumor. Positivity was defined as $\geq 1 \%$ in both TC and IC (34).
Statistical analysis. Statistical analysis was performed using V.22.0 Statistical Package for the Social Sciences (SPSS). The Fisher's exact test was used to examine associations between categorical variables and the Mann Whitney $U$-test to examine differences in groups of quantitative measurements. The significance level was set at $<0.05$ in all cases.

\section{Results}

The mean age of the patients was 34.71 years. The studied parameters included tumor size, histologic grade, estrogen 

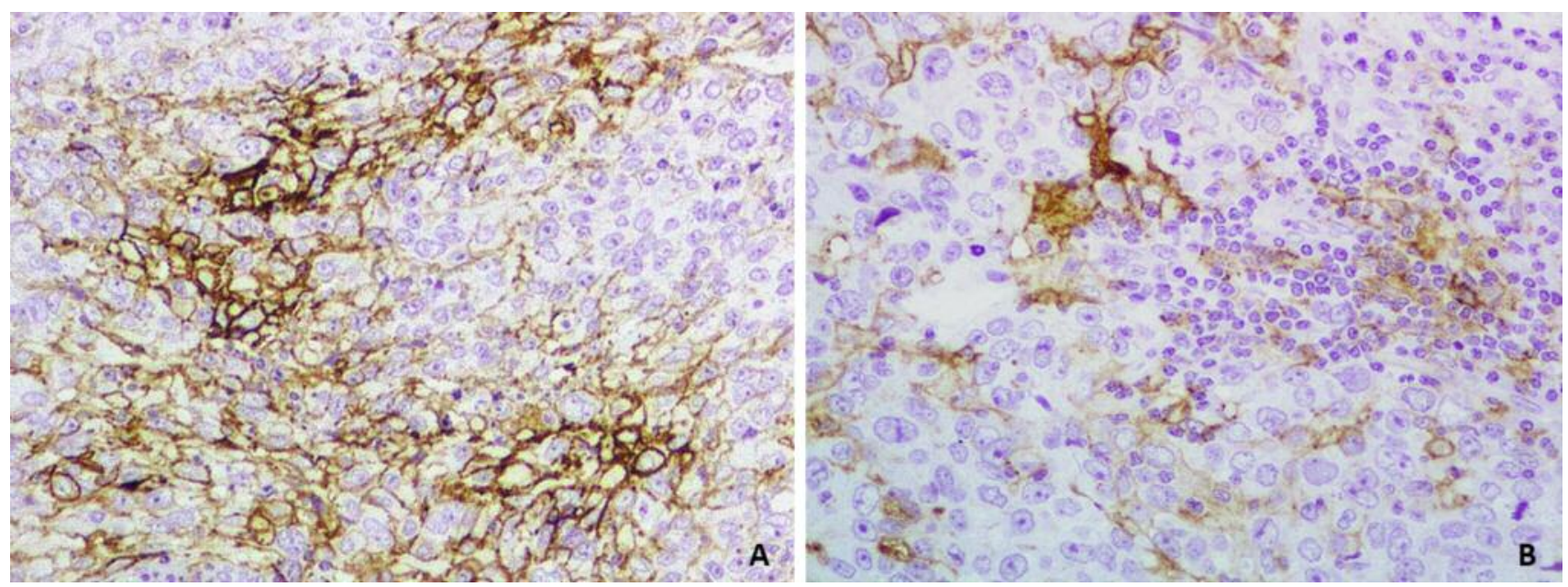

Figure 1. (A) PD-L1 expression in tumor cells $(\times 20)$. (B) PD-L1 expression in TILs and tumor cells $(\times 40)$.

receptor (ER), progesterone receptor (PR), HER2 and Ki67 expression and are shown in Table I.

Association of PDL1TC expression with clinicopathologic characteristics. Of all forty-five cases of breast cancer collected for this study, 20\% were found to have PDL1TC expression. Correlation of PDL1TC with clinicopathologic parameters showed significant association with tumor diameter, breast cancer grade, ER, PR and Ki67 expression (Table II). Specifically, PDL1TC expression revealed a significant association with carcinomas measuring more than $2 \mathrm{~cm}(36.84 \%, p=0.023)$, grade 3 IBC $(32.14 \%, p=0.017 \%)$, ER-negative status $(53.84 \%, p=0.001)$, PR-negative status $(71.42 \%, p=0,002)$ and high $\mathrm{Ki76}(32 \%, p=0.030)$ expression. PD-L1 expression assessed with continuous variables like the patients' age, tumor diameter as well as Ki67 showed significant association with the latter two $(p=0.028, p=0.000)$ (Table III). No significant association was shown between PDL1 expression and other clinicopathologic studied parameters.

Association of PDL1IC expression with clinicopathological characteristics. Inflammatory expression of PD-L1 was observed in $44.44 \%(20 / 45)$ of IBC. PD-L1 positivity in TILs showed significant association with ER, PR expression, large tumor diameter and Ki67 expression. More detailed, PDL1IC expression is most likely to be found in ER- and PR-negative cases $(84.62 \%, p=0.001,100 \%, p=0.001$, irrespectively) (Table II). Furthermore, PDL1IC expression is most commonly found in large tumor diameters and high Ki67 ( $p=0.019, p=0.04$ ), as was shown estimating the latter two parameters as continuous variables (Table III). No other significant association was shown between PDL1IC expression and other clinicopathological parameters studied.
Association of stromal TILs with clinicopathological characteristics. Of all forty-five cases collected for this study, thirteen $(28.88 \%)$ revealed high stromal TILs. The presence of high stromal TILs was significantly increased in IBC measuring more than $2 \mathrm{~cm}(52.63 \%, p=0.016)$ and in ER-negative cases $(69.23 \%, p=0,000)$ and cases with high Ki67 (44\%, $p=0.012)$. Furthermore, associating stromal TILs as a continuous variable with the patients' age, tumor diameter and Ki67, revealed that high stromal TILs are more likely to be seen in cases of IBC with a high Ki67 ( $p=0.000)$ (Table III). No significant association was found between stromal TILs and other clinicopathologic parameters.

Association of PDLITC and PDLIIC expression, stromal TILs, CD3 and CD8 lymphocytes. Both PDL1TC and PDL1IC expression in IBC cases revealed a significant association with high stromal TILs $(77.78 \%, p=0.001$, $79.92 \%, p=0.005$, respectively) (Table IV). All PDL1TC expression $(35 \%, p=0.024)$, PDL1IC $(65 \%, p=0.013)$, and high TILs $(100 \%, p=0.000)$ showed a significant association with the presence of CD3 lymphocytes. Similarly, PDL1TC expression is significantly associated with the presence of high CD8 infiltrate $(35 \%, p=0.024)$, as is PDL1IC expression $(65 \%, p=0.013)$ and high stromal TILs $(100 \%, p=0.000)$ (Table II).

\section{Discussion}

Breast cancer in premenopausal women is being increasingly detected $(8,9)$. This subgroup of women draws particular attention, because compared to older women, young age itself is a negative prognostic factor, associated with a higher risk of relapse and death (2-6). Moreover, additional concerning 
Table III. Relationship of PD-L1 expression and TILs with continuous variables.

\begin{tabular}{|c|c|c|c|}
\hline & Mean & Standard deviation & $p$-Value \\
\hline \multicolumn{4}{|l|}{ PDL1/Age } \\
\hline Negative & 35.22 & 4.599 & \multirow[t]{3}{*}{0.076} \\
\hline Positive & 32.67 & 3.742 & \\
\hline Total & 34.71 & 4.521 & \\
\hline \multicolumn{4}{|c|}{$\begin{array}{l}\text { PDL1/Tumor max } \\
\text { diameter }\end{array}$} \\
\hline Negative & 2.53 & 2.126 & \multirow[t]{3}{*}{0.028} \\
\hline Positive & 3.34 & 1.516 & \\
\hline Total & 2.69 & 2.030 & \\
\hline \multicolumn{4}{|l|}{ PDL1/Ki67 } \\
\hline Negative & 33.95 & 21.473 & \multirow[t]{3}{*}{0.000} \\
\hline Positive & 79.00 & 11.402 & \\
\hline Total & 42.30 & 26.653 & \\
\hline \multicolumn{4}{|l|}{ TILs/Age } \\
\hline Low & 34.81 & 4.935 & \multirow[t]{3}{*}{0.126} \\
\hline High & 34.46 & 3.455 & \\
\hline Total & 34.71 & 4.521 & \\
\hline \multicolumn{4}{|c|}{$\begin{array}{l}\text { TILs/Tumor max } \\
\text { diameter }\end{array}$} \\
\hline Low & 2.70 & 2.363 & \multirow[t]{3}{*}{0.527} \\
\hline High & 2.67 & 0.825 & \\
\hline Total & 2.69 & 2.030 & \\
\hline \multicolumn{4}{|l|}{ TILs/Ki67 } \\
\hline Low & 24.28 & 19.06 & \multirow[t]{3}{*}{0.000} \\
\hline High & 56.77 & 27.58 & \\
\hline Total & 33.67 & 26.18 & \\
\hline \multicolumn{4}{|l|}{ PDL1IC/Age } \\
\hline Negative & 35.12 & 4.92 & \multirow[t]{3}{*}{0.069} \\
\hline Positive & 34.20 & 4.03 & \\
\hline Total & 34.71 & 4.52 & \\
\hline \multicolumn{4}{|c|}{$\begin{array}{l}\text { PDL1IC/Tumor max } \\
\text { diameter }\end{array}$} \\
\hline Negative & 2.17 & 1.08 & \multirow[t]{3}{*}{0.019} \\
\hline Positive & 3.34 & 2.69 & \\
\hline Total & 2.69 & 2.03 & \\
\hline \multicolumn{4}{|c|}{ PDL1IC/Ki67 } \\
\hline Low & 22.76 & 17.09 & \multirow[t]{3}{*}{0.04} \\
\hline High & 47.30 & 29.42 & \\
\hline Total & 33.67 & 26.18 & \\
\hline
\end{tabular}

issues regarding the quality of life of this population are being encountered such as fertility preservation, pregnancy, sexual life and external appearance $(8,11)$. It is therefore important, to enrich our knowledge in the tumor microenvironment, a hallmark of cancer in this particular group (14). Although various studies exist examining PD-L1 expression and TILs in breast cancer, this is one of the few studies to focus on this specific age subgroup.

The results of this study indicate that high stromal TILs are only found in a minority of cases, which is consistent with other reports studying TILs in IBC in women of all ages $(26,35)$. PD-L1 on the contrary, has a very wide spectrum of expression on TC and IC in IBC cases, as is reported in the literature, with a positivity range approximately from $20 \%$ to almost $60 \%$ and $2 \%$ to $90 \%$, respectively (36-41). Of all forty-five cases of IBC included in our study, we observed nine $(20 \%)$ cases of PDL1TC expression and twenty cases of PDL1IC expression (44.44\%), both of which apply in the range. A possible explanation for having only a minority of cases expressing PDL1TC and high stromal TILs, is the fact that high stromal TILs and PD-L1 expression are most commonly encountered in TNC, which are less frequent (37). Thus, a possible explanation for having only a minimum positivity of PDL1TC in this study is the limited number of TNC in our cohort. Furthermore, we have shown that PDL1TC positive cases are more seldom found than PDL1IC positive cases, which is consistent with other studies (42).

Associations between PDL1TC and clinicopathological parameters revealed a positive correlation between this expression and grade 3 IBC, ER and PR negativity, as well as large tumor diameter and higher Ki67 expression. No statistically significant associations were found between PDL1TC and other clinicopathologic parameters. These findings are consistent with most studies found in the literature (43-46). The association between PDL1TC and HER2 status remains controversial, though (41, 47). In our study we did not find any correlation between PDL1TC expression and HER2 positive IBC which is consistent with a meta-analysis performed from Huang et al. (41) in which 47 studies were included, conducted between the years 20062018. A possible explanation for this heterogeneity between PDL1TC expression and HER2 status in the various studies could be the lack of standardized methodology of measurement of PD-L1 (41).

There are not many studies focusing on the expression of PD-L1 on TILs, but the results regarding the relationship between the latter with various clinicopathologic parameters are consistent $(39,48,49)$. Similarly, the results of our study indicated that patients with PDL1IC IBC are most likely to have ER or PR negative carcinomas, large tumor diameter and high Ki67, all of which are established indicators of poor prognosis.

High stromal TILs, PLD1TC and PDL1IC expression were found to be associated with each other, which validates previous reports $(35,37,39,50)$. Furthermore, we indicated that high stromal TILs are more commonly answered in ER negative cases and high Ki67 expression, which shows no deviation from existing reports $(51,52)$. We already know that high stromal TILs are more commonly answered in HER2+ IBC, but this conclusion could not have been conducted in our study, possibly due to the limited number of HER2+ cases (52).

Further analysis of stromal TILs revealed a statistically significant association between high stromal TILs, PDL1TC and PDL1IC with the presence of high $\mathrm{CD}^{+}$and $\mathrm{CD}^{+} \mathrm{T}$ 
Table IV. PDL1TC and PDL1IC expression and TILs correlation.

\begin{tabular}{|c|c|c|c|c|c|c|}
\hline & \multicolumn{3}{|c|}{ PDL1TC } & \multicolumn{3}{|c|}{ PDL1IC } \\
\hline & Positive $(n=9)$ & Negative $(n=36)$ & $p$-Value & Positive $(n=20)$ & Negative $(n=25)$ & $p$-Value \\
\hline \multicolumn{7}{|l|}{ TILS } \\
\hline High $(n=13)$ & $7(77.78 \%)$ & $6(16.67 \%)$ & 0.001 & $10(79.92 \%)$ & $3(23.07 \%)$ & 0.005 \\
\hline Low $(n=32)$ & $2(22.22 \%)$ & $30(83.33 \%)$ & & $10(31.25 \%)$ & $22(68.75 \%)$ & \\
\hline
\end{tabular}

lymphocytes. TILs are composed by several B and T types of lymphocytes, each of them with a different prognostic value (53).There are various types of T lymphocytes and it is worth mentioning that most $\mathrm{CD}^{+} \mathrm{T}$ lymphocytes are also $\mathrm{CD}^{+}$ positive $(54,55)$. Denkert et al. (26) indicate that TILs, regardless of their composition, are linked to an improved prognosis, but there are also many studies focusing on the prognostic value of the various types of cells composing TILs. For instance, Seo et al. (56) showed that the increased number of $\mathrm{CD}^{+} \mathrm{T}$ cells is linked to a better clinical outcome and $\mathrm{CD}^{+}$lymphocytes are associated with a better prognosis in IBC while Teschendorff et al. (57) indicated that Th2 cells, a $\mathrm{CD}^{+}{ }^{+}$subpopulation, are linked to mediating the antitumor response, thus having a negative prognostic value. Mori et al. (58) conjectured that the subtypes of TILs should be considered in future studies, because their variations lead to a heterogeneity of conclusions conducted regarding the RFS and OS. Nevertheless, despite having an heterogeneity of opinions between various studies, it is safe to say that our results indicate that young women with high stromal TILs and/or PDL1TC and/or PDL1IC expression are more likely to have a high $\mathrm{CD}^{+}$lymphocyte and a high $\mathrm{CD}^{+}$infiltrate. Both findings are linked to a better clinical outcome as proven from the studies mentioned above.

Many studies have been conducted in order to evaluate the prognostic value of PDL1TC, PDL1IC and TILs in IBC, and even after many meta-analyses some results remain conflicting $(41,59,60)$. Kim et al. (60), conducted an meta-analysis which included 7,877 cases and was led to the conclusion that PDL1TC expression is associated with poorer DFS. No association was found between PDL1 expression and OS, to the contrast with the meta-analysis conducted by Huang et al. which found that PDL1TC expression is linked to a poorer DFS but also OS. In the present study PDL1TC expression was proven to be linked to several unfavorable prognostic factors, which could indicate a poor prognosis. Although the PD-L1 expression on TILs has not yet been thoroughly examined in the literature, it seems from the existing studies that it is of great prognostic value (61). From these studies PDL1IC expression has shown to have opposite prognostic value compared to PDL1TC expression, since most cases are related to higher DFS, RFS as well as OS $(41,62)$. Zhao et al. (61) studied the prognostic value of PDL1IC expression on several solid tumors, and indicated that it is a positive prognostic factor, especially in IBC. Briefly, a possible explanation for this result, is the fact that PDL1TC expression is mostly driven intercellularly through the tumor-intrinsic mechanism, whereas the PDL1IC expression is driven via adaptive mechanisms, thus related to high stromal TILs which are an anti-tumor answer as a result of an activated PD1/PDL1 pathway (63). The diversity of prognosis between these two factors indicates the importance of the evaluation of PD-L1 expression on both TC and IC in carcinomas. High stromal TILs per se are linked to an improved patient survival and numerous studies focusing on treating such patients with neoadjuvant systemic therapy have shown that the presence of high stromal TILs is in favor of complete pathological response, thus excellent prognosis. Similarly results were found in patients with high $\mathrm{CD}^{+}$infiltrate $(37,39)$.

Undeniable, the discovery of TILs as well as the PD1/PD-L1 axis has opened new horizons in understanding the response of the host immune system and the way it associates with tumor progression. Thus, established targeted therapy against ER and $\mathrm{PR}$, as well as human epidermal growth factor receptor 2 (HER2), are already getting enriched with the introduction of immunotherapy, showing very promising results (64). Our opinion is that as in other age groups, stromal TILs and PDL1TC and PDL1IC could be used as prognostic factors and immunotherapy will complement the existent targeted therapies.

Our study has certain limitations especially because of its retrospective nature and its small number of cases studied, as well as the absence of prognostic information. However, it is conducted in a particular patient group where scarce data actually exist. Breast cancer in younger women was rarely identified in the past but now shows an increased number of diagnoses and unfavorable prognosis $(8,9)$. This indicates that although major progress has been achieved in prognosis, diagnosis and treatment in elderly women, this does not yet apply in young women. Several studies have been conducted focusing on whether young breast cancer could have special characteristic or not $(13,65)$. This is the first study to compare clinicopathologic parameters with PD-L1 expression and stromal TILs focusing on this specific age group.

In conclusion, the results of our study show that the PDL1, CD3 and CD8 expression status in younger women are 
similar to other age groups as reported in the literature. Thus, the latter parameters should be evaluated and reported in order to be used in cases of young women with IBC and complement existing targeted therapies with immunotherapy, aiming for a better outcome.

\section{Conflicts of Interest}

All Authors declare that they have no conflicts of interest.

\section{Authors' Contributions}

Zoi Evangelou and Anna Batistatou have designed the study. Zoi Evangelou, Alexandra Papoudou-Bai, Georgia Karpathiou, Helen Kourea, Sevasti Kamina and Anna Goussia have contributed to the data. Haralambos Harissis has contributed to the acquisition and examination of the original material. Dimitrios Peschos has contributed to the analysis of data. All Authors have read and approved the manuscript.

\section{References}

1 Torre LA, Siegel RL, Ward EM and Jemal A: Global cancer incidence and mortality rates and trends-an update. Cancer Epidemiol Biomarkers Prev 25: 16-27, 2016. PMID: 26667886. DOI: 10.1158/1055-9965.EPI-15-0578

2 Anders CK, Hsu DS, Broadwater G, Acharya CR, Foekens JA, Zhang Y, Wang Y, Marcom PK, Marks JR, Febbo PG, Nevins JR, Potti A and Blackwell KL: Young age at diagnosis correlates with worse prognosis and defines a subset of breast cancers with shared patterns of gene expression. J Clin Oncol 26: 3324-3330, 2008. PMID: 18612148. DOI: 10.1200/JCO.2007.14.2471

3 Bartelink H, Horiot J-C, Poortmans PM, Struikmans H, Van den Bogaert W, Fourquet A, Jager JJ, Hoogenraad WJ, Oei SB, Wárlám-Rodenhuis CC, Pierart M and Collette L: Impact of a higher radiation dose on local control and survival in breastconserving therapy of early breast cancer: 10-year results of the randomized boost versus no boost EORTC 22881-10882 trial. J Clin Oncol 25: 3259-3265, 2007. PMID: 17577015. DOI: 10.1200/JCO.2007.11.4991

4 Anders CK, Johnson R, Litton J, Phillips M and Bleyer A: Breast cancer before age 40 years. Semin Oncol 36: 237-249, 2009. PMID: 19460581. DOI: 10.1053/j.seminoncol.2009.03.001

5 Fredholm H, Eaker S, Frisell J, Holmberg L, Fredriksson I and Lindman $\mathrm{H}$ : Breast cancer in young women: poor survival despite intensive treatment. PLoS One 4: e7695, 2009. PMID: 19907646. DOI: 10.1371/journal.pone.0007695

6 Bharat A, Aft RL, Gao F and Margenthaler JA: Patient and tumor characteristics associated with increased mortality in young women ( $\leq 40$ years) with breast cancer. J Surg Oncol 100: 248-251, 2009. PMID: 19330813. DOI: 10.1002/jso.21268

7 Maltaris T, Beckmann MW and Dittrich R: Review. Fertility preservation for young female cancer patients. In Vivo 23: 123130, 2009. PMID: 19368136.

8 Cardoso F, Loibl S, Pagani O, Graziottin A, Panizza P, Martincich L, Gentilini O, Peccatori F, Fourquet A, Delaloge S, Marotti L, Penault-Llorca F, Kotti-Kitromilidou AM, Rodger A and Harbeck N: The European Society of Breast Cancer Specialists recommendations for the management of young women with breast cancer. Eur J Cancer 48: 3355-3377, 2012. PMID: 23116682. DOI: 10.1016/j.ejca.2012.10.004

9 Brinton LA, Sherman ME, Carreon JD and Anderson WF: Recent trends in breast cancer among younger women in the United States. JNCI J Natl Cancer Inst 100: 1643-1648, 2008. PMID: 19001605. DOI: 10.1093/jnci/djn344

10 Ribnikar D, Ribeiro JM, Pinto D, Sousa B, Pinto AC, Gomes E, Moser EC, Cardoso MJ and Cardoso F: Breast cancer under age 40: a different approach. Curr Treat Options Oncol 16: 16, 2015. PMID: 25796377. DOI: 10.1007/s11864-015-0334-8

11 Paluch-Shimon S, Pagani O, Partridge AH, Bar-Meir E, Fallowfield L, Fenlon D, Friedman E, Gelmon K, Gentilini O, Geraghty J, Harbeck N, Higgins S, Loibl S, Moser E, Peccatori F, Raanani H, Kaufman B and Cardoso F: Second international consensus guidelines for breast cancer in young women (BCY2). The Breast 26: 87-99, 2016. PMID: 27017247. DOI: 10.1016/ j.breast.2015.12.010

12 Reis-Filho JS and Pusztai L: Gene expression profiling in breast cancer: classification, prognostication, and prediction. Lancet 378: 1812-1823, 2011. PMID: 22098854. DOI: 10.1016/S01406736(11)61539-0

13 Fu J, Wu L, Fu W, Tan Y, Xu T, Hong Z, Wang F and Li S: How young is too young in breast cancer? Young breast cancer is not a unique biological subtype. Clin Breast Cancer 18: e25-e39, 2018. PMID: 28802528. DOI: $10.1016 /$ j.clbc.2017.05.015

14 Hanahan D and Weinberg RA: Hallmarks of cancer: The next generation. Cell 144: 646-674, 2011. PMID: 21376230. DOI: 10.1016/j.cell.2011.02.013

$15 \mathrm{Ma}$ W, Gilligan BM, Yuan $\mathrm{J}$ and Li T: Current status and perspectives in translational biomarker research for PD-1/PD-L1 immune checkpoint blockade therapy. J Hematol Oncol 9: 47, 2016. DOI: 10.1186/s13045-016-0277-y

16 Asano Y, Kashiwagi S, Goto W, Takada K, Takahashi K, Hatano T, Takashima T, Tomita S, Motomura H, Ohsawa M, Hirakawa $\mathrm{K}$ and Ohira M: Prediction of treatment response to neoadjuvant chemotherapy in breast cancer by subtype using tumorinfiltrating lymphocytes. Anticancer Res 38: 2311-2321, 2018. PMID: 29599354 DOI: 10.21873/anticanres.12476

17 Papaioannou E, Sakellakis M, Melachrinou M, Tzoracoleftherakis E, Kalofonos $\mathrm{H}$ and Kourea E: A standardized evaluation method for FOXP3+ Tregs and CD8+ T-cells in breast carcinoma: Association with breast carcinoma subtypes, stage and prognosis. Anticancer Res 39: 1217-1232, 2019. PMID: 26408698.

18 Pagès F, Berger A, Camus M, Sanchez-Cabo F, Costes A, Molidor R, Mlecnik B, Kirilovsky A, Nilsson M, Damotte D, Meatchi T, Bruneval P, Cugnenc P-H, Trajanoski Z, Fridman W$\mathrm{H}$ and Galon J: Effector memory $\mathrm{T}$ cells, early metastasis, and survival in colorectal cancer. N Engl J Med 353: 2654-2666, 2005. PMID: 16371631. DOI: 10.1056/NEJMoa051424

19 Zhang L, Conejo-Garcia JR, Katsaros D, Gimotty PA, Massobrio M, Regnani G, Makrigiannakis A, Gray H, Schlienger K, Liebman MN, Rubin SC and Coukos G: Intratumoral T cells, recurrence, and survival in epithelial ovarian cancer. N Engl J Med 348: 203-213, 2003. PMID: 12529460. DOI: 10.1056/ NEJMoa020177

20 Bromwich EJ, McArdle PA, Canna K, McMillan DC, McNicol AM, Brown $\mathrm{M}$ and Aitchison $\mathrm{M}$ : The relationship between Tlymphocyte infiltration, stage, tumour grade and survival in patients undergoing curative surgery for renal cell cancer. Br J Cancer 89: 1906-1908, 2003. PMID: 14612901. DOI: 10.1038/sj.bjc.6601400 
21 McArdle PA, Canna K, McMillan DC, McNicol A-M, Campbell R and Underwood MA: The relationship between T-lymphocyte subset infiltration and survival in patients with prostate cancer. Br J Cancer 91: 541-543, 2004. PMID: 15266325. DOI: 10.1038/sj.bjc.6601943

22 Karpathiou G, Casteillo F, Giroult J-B, Forest F, Fournel P, Monaya A, Froudarakis M, Dumollard JM, Prades JM and Peoc'h M: Prognostic impact of immune microenvironment in laryngeal and pharyngeal squamous cell carcinoma: Immune cell subtypes, immuno-suppressive pathways and clinicopathologic characteristics. Oncotarget 8, 2017. PMID: 28038471. DOI: 10.18632/oncotarget.14242

23 Adams S, Gray RJ, Demaria S, Goldstein L, Perez EA, Shulman LN, Martino S, Wang M, Jones VE, Saphner TJ, Wolff AC, Wood WC, Davidson NE, Sledge GW, Sparano JA and Badve SS: Prognostic value of tumor-infiltrating lymphocytes in triple-negative breast cancers from two phase III randomized adjuvant breast cancer trials: ECOG 2197 and ECOG 1199. J Clin Oncol 32: 29592966, 2014. PMID: 25071121. DOI: 10.1200/JCO.2013.55.0491

24 Loi S, Sirtaine N, Piette F, Salgado R, Viale G, Van Eenoo F, Rouas G, Francis P, Crown JPA, Hitre E, de Azambuja E, Quinaux E, Di Leo A, Michiels S, Piccart MJ and Sotiriou C: Prognostic and predictive value of tumor-infiltrating lymphocytes in a phase III randomized adjuvant breast cancer trial in node-positive breast cancer comparing the addition of docetaxel to doxorubicin with doxorubicin-based chemotherapy: BIG 02-98. J Clin Oncol 31: 860867, 2013. PMID: 23341518. DOI: 10.1200/JCO.2011.41.0902

25 Lee M-C, Buitrago DH, Kadota K, Ujiie H, Woo K, Sima CS, Travis WD, Jones DR and Adusumilli PS: The tumor immune microenvironment in octogenarians with stage I non-small cell lung cancer. Oncoimmunology 3: e967142, 2014. PMID: 25941595. DOI: $10.4161 / 21624011.2014 .967142$

26 Denkert C, Loibl S, Noske A, Roller M, Müller BM, Komor M, Budczies J, Darb-Esfahani S, Kronenwett R, Hanusch C, von Törne C, Weichert W, Engels K, Solbach C, Schrader I, Dietel $\mathrm{M}$ and von Minckwitz G: Tumor-associated lymphocytes as an independent predictor of response to neoadjuvant chemotherapy in breast cancer. J Clin Oncol 28: 105-113, 2010. PMID: 19917869. DOI: $10.1200 / \mathrm{JCO} .2009 .23 .7370$

27 Zou W and Chen L: Inhibitory B7-family molecules in the tumour microenvironment. Nat Rev Immunol 8: 467-477, 2008. PMID: 18500231. DOI: $10.1038 / \mathrm{nri} 2326$

28 Woo S-R, Turnis ME, Goldberg M V., Bankoti J, Selby M, Nirschl CJ, Bettini ML, Gravano DM, Vogel P, Liu CL, Tangsombatvisit S, Grosso JF, Netto G, Smeltzer MP, Chaux A, Utz PJ, Workman CJ, Pardoll DM, Korman AJ, Drake CG and Vignali DAA: Immune inhibitory molecules LAG-3 and PD-1 synergistically regulate t-cell function to promote tumoral immune escape. Cancer Res 72: 917-927, 2012. PMID: 22186141. DOI: 10.1158/0008-5472.CAN-11-1620

29 Brahmer JR, Tykodi SS, Chow LQM, Hwu W-J, Topalian SL, Hwu P, Drake CG, Camacho LH, Kauh J, Odunsi K, Pitot HC, Hamid O, Bhatia S, Martins R, Eaton K, Chen S, Salay TM, Alaparthy S, Grosso JF, Korman AJ, Parker SM, Agrawal S, Goldberg SM, Pardoll DM, Gupta A and Wigginton JM: Safety and activity of anti-PD-L1 antibody in patients with advanced cancer. N Engl J Med 366: 2455-2465, 2012. PMID: 22658128. DOI: $10.1056 /$ NEJMoa1200694

30 Gajewski TF, Schreiber H and Fu Y-X: Innate and adaptive immune cells in the tumor microenvironment. Nat Immunol 14: 1014-1022, 2013. PMID: 24048123. DOI: 10.1038/ni.2703
31 Azuma T, Yao S, Zhu G, Flies AS, Flies SJ and Chen L: B7-H1 is a ubiquitous antiapoptotic receptor on cancer cells. Blood 111: 36353643, 2008. PMID: 18223165. DOI: 10.1182/blood-2007-11-123141

32 Salgado R, Denkert C, Demaria S, Sirtaine N, Klauschen F, Pruneri G, Wienert S, Van den Eynden G, Baehner FL, PenaultLlorca F, Perez EA, Thompson EA, Symmans WF, Richardson AL, Brock J, Criscitiello C, Bailey H, Ignatiadis M, Floris G, Sparano J, Kos Z, Nielsen T, Rimm DL, Allison KH, Reis-Filho JS, Loibl S, Sotiriou C, Viale G, Badve S, Adams S, WillardGallo $\mathrm{K}$ and Loi $\mathrm{S}$ : The evaluation of tumor-infiltrating lymphocytes (TILs) in breast cancer: recommendations by an International TILs Working Group 2014. Ann Oncol 26: 259271, 2015. PMID: 25214542. DOI: 10.1093/annonc/mdu450

33 Guo X, Fan Y, Lang R, Gu F, Chen L, Cui L, Pringle GA, Zhang $\mathrm{X}$ and $\mathrm{Fu} \mathrm{L}$ : Tumor infiltrating lymphocytes differ in invasive micropapillary carcinoma and medullary carcinoma of breast. Mod Pathol 21: 1101-1107, 2008. PMID: 18469794. DOI: 10.1038/modpathol.2008.72

34 Downes MR, Slodkowska E, Katabi N, Jungbluth AA and Xu B: Inter- and intraobserver agreement of programmed death ligand 1 scoring in head and neck squamous cell carcinoma, urothelial carcinoma and breast carcinoma. Histopathology 76: 189-190, 2019. PMID: 31243779. DOI: 10.1111/his.13946

35 Lee AH, Happerfield LC, Millis RR and Bobrow LG: Inflammatory infiltrate in invasive lobular and ductal carcinoma of the breast. Br J Cancer 74: 796-801, 1996. PMID: 8795584. DOI: $10.1038 /$ bjc. 1996.438

36 Schalper KA, Velcheti V, Carvajal D, Wimberly H, Brown J, Pusztai L and Rimm DL: In situ tumor PD-L1 mRNA expression is associated with increased TILs and better outcome in breast carcinomas. Clin Cancer Res 20: 2773-2782, 2014. PMID: 24647569. DOI: $10.1158 / 1078-0432$.CCR-13-2702

37 Sabatier R, Finetti P, Mamessier E, Adelaide J, Chaffanet M, Ali HR, Viens P, Caldas C, Birnbaum D and Bertucci F: Prognostic and predictive value of PDL1 expression in breast cancer. Oncotarget 6, 2015. PMID: 25669979. DOI: 10.18632/oncotarget.3216

38 Ghebeh H, Tulbah A, Mohammed S, ElKum N, Amer SM Bin, Al-Tweigeri T and Dermime S: Expression of B7-H1 in breast cancer patients is strongly associated with high proliferative $\mathrm{Ki}$ 67-expressing tumor cells. Int J Cancer 121: 751-758, 2007. PMID: 17415709 . DOI: 10.1002/ijc.22703

39 Ghebeh H, Mohammed S, Al-Omair A, Qattant A, Lehe C, AlQudaihi G, Elkum N, Alshabanah M, Bin Amer S, Tulbah A, Ajarim D, Al-Tweigeri T and Dermime S: The B7-H1 (PD-L1) $\mathrm{T}$ lymphocyte-inhibitory molecule is expressed in breast cancer patients with infiltrating ductal carcinoma: Correlation with important high-risk prognostic factors. Neoplasia 8: 190-198, 2006. PMID: 16611412. DOI: 10.1593/neo.05733

40 Muenst S, Schaerli AR, Gao F, Däster S, Trella E, Droeser RA, Muraro MG, Zajac P, Zanetti R, Gillanders WE, Weber WP and Soysal SD: Expression of programmed death ligand 1 (PD-L1) is associated with poor prognosis in human breast cancer. Breast Cancer Res Treat 146: 15-24, 2014. PMID: 24842267. DOI: 10.1007/s 10549-014-2988-5

41 Huang W, Ran R, Shao B and Li H: Prognostic and clinicopathological value of PD-L1 expression in primary breast cancer: a meta-analysis. Breast Cancer Res Treat, 2019. PMID: 31359214. DOI: 10.1007/s10549-019-05371-0

42 Dill EA, Gru AA, Atkins KA, Friedman LA, Moore ME, Bullock TN, Cross JV, Dillon PM and Mills AM: PD-L1 
Expression and intratumoral heterogeneity across breast cancer subtypes and stages. Am J Surg Pathol 41: 334-342, 2017. PMID: 28195880. DOI: 10.1097/PAS.0000000000000780

43 Bae SB, Cho HD, Oh M-H, Lee J-H, Jang S-H, Hong SA, Cho J, Kim SY, Han SW, Lee JE, Kim HJ and Lee HJ: Expression of programmed death receptor ligand 1 with high tumor-infiltrating lymphocytes is associated with better prognosis in breast cancer. J Breast Cancer 19: 242, 2016. PMID: 27721873. DOI: 10.4048/ jbc.2016.19.3.242

44 Buisseret L, Garaud S, de Wind A, Van den Eynden G, Boisson A, Solinas C, Gu-Trantien C, Naveaux C, Lodewyckx J-N, Duvillier H, Craciun L, Veys I, Larsimont D, Piccart-Gebhart M, Stagg J, Sotiriou C and Willard-Gallo K: Tumor-infiltrating lymphocyte composition, organization and PD-1/PD-L1 expression are linked in breast cancer. Oncoimmunology 6: e1257452, 2017. PMID: 28197375. DOI: 10.1080/ 2162402X.2016.1257452

45 Qin T, Zeng Y, Qin G, Xu F, Lu J, Fang W, Xue C, Zhan J, Zhang X, Zheng Q, Peng R, Yuan Z, Zhang L and Wang S: High PD-L1 expression was associated with poor prognosis in 870 Chinese patients with breast cancer. Oncotarget 6, 2015. PMID: 28430626. DOI: 10.18632 /oncotarget.15532

46 Wang Z-Q, Milne K, Derocher H, Webb JR, Nelson BH and Watson PH: PD-L1 and intratumoral immune response in breast cancer. Oncotarget 8, 2017. PMID: 28881675. DOI: 10.18632/ oncotarget.18305

47 Li S, Chen L and Jiang J: Role of programmed cell death ligand1 expression on prognostic and overall survival of breast cancer Medicine (Baltimore) 98: e15201, 2019. PMID: 31008945. DOI: 10.1097/MD.0000000000015201

48 Kim A, Lee SJ, Kim YK, Park WY, Park DY, Kim JY, Lee CH, Gong G, Huh GY and Choi KU: Programmed death-ligand 1 (PD-L1) expression in tumour cell and tumour infiltrating lymphocytes of HER2-positive breast cancer and its prognostic value. Sci Rep 7: 11671, 2017. PMID: 28916815. DOI: 10.1038/s41598-017-11905-7

49 Botti G, Collina F, Scognamiglio G, Rao F, Peluso V, De Cecio R, Piezzo M, Landi G, De Laurentiis M, Cantile M and Di Bonito M: Programmed death ligand 1 (PD-L1) tumor expression is associated with a better prognosis and diabetic disease in triple negative breast cancer patients. Int J Mol Sci 18: 459, 2017. PMID: 28230773. DOI: 10.3390/ijms 18020459

50 Cimino-Mathews A, Thompson E, Taube JM, Ye X, Lu Y, Meeker A, Xu H, Sharma R, Lecksell K, Cornish TC, Cuka N, Argani P and Emens LA: PD-L1 (B7-H1) expression and the immune tumor microenvironment in primary and metastatic breast carcinomas. Hum Pathol 47: 52-63, 2016. PMID: 26527522. DOI: 10.1016/j.humpath.2015.09.003

51 Polónia A, Pinto R, Cameselle-Teijeiro JF, Schmitt FC and Paredes J: Prognostic value of stromal tumour infiltrating lymphocytes and programmed cell death-ligand 1 expression in breast cancer. J Clin Pathol 70: 860-867, 2017. PMID: 28373294. DOI: $10.1136 /$ jclinpath-2016-203990

52 Stanton SE and Disis ML: Clinical significance of tumorinfiltrating lymphocytes in breast cancer. J Immunother Cancer 4: 59, 2016. PMID: 27777769. DOI: 10.1186/s40425-016-0165-6

53 Gooden MJM, de Bock GH, Leffers N, Daemen T and Nijman HW: The prognostic influence of tumour-infiltrating lymphocytes in cancer: a systematic review with meta-analysis. Br J Cancer 105: 93-103, 2011. PMID: 21629244. DOI: 10.1038/bjc.2011.189
54 Iwai Y, Ishida M, Tanaka Y, Okazaki T, Honjo T and Minato N: Involvement of PD-L1 on tumor cells in the escape from host immune system and tumor immunotherapy by PD-L1 blockade. Proc Natl Acad Sci 99: 12293-12297, 2002. PMID: 12218188. DOI: $10.1073 /$ pnas.192461099

55 Hirano F, Kaneko K, Tamura H, Dong H, Wang S, Ichikawa M, Rietz C, Flies DB, Lau JS, Zhu G, Tamada K and Chen L: Blockade of B7-H1 and PD-1 by monoclonal antibodies potentiates cancer therapeutic immunity. Cancer Res 65: 108996, 2005. PMID: 15705911.

56 Seo S-K, Seo H-M, Jeong H-Y, Choi I-W, Park Y-M, Yagita H, Chen L and Choi I-H: Co-inhibitory role of T-cell-associated B7$\mathrm{H} 1$ and B7-DC in the T-cell immune response. Immunol Lett 102: 222-228, 2006. PMID: 16236366. DOI: 10.1016/j.imlet. 2005.09.007

57 Teschendorff AE, Gomez S, Arenas A, El-Ashry D, Schmidt M, Gehrmann $M$ and Caldas C: Improved prognostic classification of breast cancer defined by antagonistic activation patterns of immune response pathway modules. BMC Cancer 10: 604, 2010. PMID: 21050467. DOI: 10.1186/1471-2407-10-604

58 Mori H, Kubo M, Yamaguchi R, Nishimura R, Osako T, Arima N, Okumura Y, Okido M, Yamada M, Kai M, Kishimoto J, Oda $\mathrm{Y}$ and Nakamura M: The combination of PD-L1 expression and decreased tumor-infiltrating lymphocytes is associated with a poor prognosis in triple-negative breast cancer. Oncotarget 8 , 2017. PMID: 28107186. DOI: 10.18632/oncotarget.14698

59 Uhercik M, Sanders A, Owen S, Davies E, Sharma A, Jiang W and Mokbel K: Clinical significance of PD1 and PDL1 in human breast cancer. Anticancer Res 37: 4249-4254, 2017. PMID: 28739716. DOI: $10.21873 /$ anticanres. 11817

$60 \mathrm{Kim}$ HM, Lee J and Koo JS: Clinicopathological and prognostic significance of programmed death ligand-1 expression in breast cancer: a meta-analysis. BMC Cancer 17: 690, 2017. PMID: 29041905. DOI: 10.1186/s12885-017-3670-1

61 Zhao T, Li C, Wu Y, Li B and Zhang B: Prognostic value of PDL1 expression in tumor infiltrating immune cells in cancers: A meta-analysis. PLoS One 12: e0176822, 2017. PMID: 28453554. DOI: 10.1371/journal.pone. 0176822

62 Li X, Wetherilt CS, Krishnamurti U, Yang J, Ma Y, Styblo TM, Meisel JL, Peng L, Siddiqui MT, Cohen C and Aneja R: Stromal PD-L1 expression is associated with better disease-free survival in triple-negative breast cancer. Am J Clin Pathol 146: 496-502, 2016. PMID: 27686176. DOI: 10.1093/ajcp/aqw134

63 Kim HR, Ha S-J, Hong MH, Heo SJ, Koh YW, Choi EC, Kim EK, Pyo KH, Jung I, Seo D, Choi J, Cho BC and Yoon SO: PDL1 expression on immune cells, but not on tumor cells, is a favorable prognostic factor for head and neck cancer patients. Sci Rep 6: 36956, 2016. PMID: 27841362. DOI: 10.1038/srep36956

$64 \mathrm{Katz} \mathrm{H}$ and Alsharedi M: Immunotherapy in triple-negative breast cancer. Med Oncol 35: 13, 2018. PMID: 29255938. DOI: 10.1007/s 12032-017-1071-6

65 Fredholm H, Magnusson K, Lindström LS, Tobin NP, Lindman H, Bergh J, Holmberg L, Pontén F, Frisell J and Fredriksson I: Breast cancer in young women and prognosis: How important are proliferation markers? Eur J Cancer 84: 278-289, 2017. PMID: 28844016. DOI: 10.1016/j.ejca.2017.07.044

Received December 6, 2019

Revised December 17, 2019

Accepted January 8, 2020 